Maneto: The Temple University Multi-Disciplinary Undergraduate Research Journal | 2.1

\title{
Neocolonialism and the Ecological Crisis of the Suez Canal Ritapa Neogi
}

Abstract

Since its construction in the mid-1800's, Egypt's Suez Canal has been a source of international conflict, economic growth, and ecological turmoil. Because it regularly transports a large number of oil tankers from the Suez Port to Port Said, the canal is one of the most valuable waterways in the world. However, in linking the Mediterranean and Red Sea, the canal has caused hundreds of invasive species to migrate to the Mediterranean -- most notably invasive sea jellies. This has led to damaging effects on industries surrounding the welfare of the sea; for example, fisheries and tourism. In late 2015, despite these ecological concerns, the canal was expanded to include a parallel channel, allowing for two-way travel.

While supporters envisioned positive transformations to Egypt's high poverty and unemployment rates, the expansion's possible long-term effects on the ocean and industries based on the ocean were neglected in discussion. My goal is to examine these ongoing effects and their consequences on humans whose livelihoods depend on the Mediterranean Sea as a resource, with a focus on how the influx of migrating species, specifically gelatinous zooplankton, have already affected fisheries, agriculture, and tourism. I also look at the eutrophication of nearby waters through chemical disposal from local factories, one of the causes of jellyfish blooms. While the Suez Canal has led to much economic growth for Egypt, the waterway's growing negative ecological effects may override its positive influences in the long run. 
Maneto: The Temple University Multi-Disciplinary Undergraduate Research Journal | 2.1

To some, the Suez Canal may not signify a long-standing symbol of colonialism. After all, it brings Egypt an enormous amount of wealth, surviving as the country's main source of income and success for hundreds of years. However, since its construction in the mid-1800's, Egypt's Suez Canal has been a source of international conflict, economic growth, and ecological turmoil. Because it regularly transports a large number of oil tankers from the Suez Port to Port Said, the canal is one of the most valuable waterways in the world. But in linking the Mediterranean and Red Sea, the canal has caused hundreds of invasive species to migrate to the Mediterranean, most notably invasive sea jellies. This has led to damaging effects on industries surrounding the welfare of the sea, specifically fisheries and tourism. Through French and British rule, the nation of Egypt became dependent on these industries, directly resulting in the eutrophication of the Red Sea. Thus, it is clear that Lessepsian migration is not only a matter of science, but also a matter of neocolonialism.

In late 2015, despite these ecological concerns, the canal was expanded to include a parallel channel, allowing for two-way travel. While supporters envisioned positive transformations to Egypt's high poverty and unemployment rates, the expansion's possible longterm effects on the ocean and industries based on the ocean were neglected in discussion. My goal is to examine these ongoing effects and their consequences on humans whose livelihoods depend on the Mediterranean Sea as a resource, with a focus on how the influx of migrating species, specifically gelatinous zooplankton, have already affected fisheries, agriculture, and tourism. I will address how Egypt's ongoing reliance on industries formed by the French and British continue to affect bodies of water in Northern Africa and Southwest Asia. While the Suez Canal has led to much economic growth for Egypt, the waterway's growing negative ecological effects may override its positive influences in the long run.

Seeing that the Suez Canal was built as a result of modernist capitalism and colonialism, it is necessary to overview the history of both in Egypt. The French colonialism of Egypt began in 1798 , led by Napoleon Bonaparte. The British invaded nearly a century later, then colonized Iraq, Palestine, and Syria, alongside the French, who took Syria in 1918 and created Lebanon two years later (Attar 2010). Under the monarchal Ottoman Empire's new ordinance in 1830, two decades after the French retreated, Egyptians were often treated as prisoners in their own countries, restrained to their native districts, forced to surrender their produce, and drafted into 
Maneto: The Temple University Multi-Disciplinary Undergraduate Research Journal | 2.1

military camps (Mitchell 1991, p. 34). For the duration of the 19th century, power was redirected in a Foucauldian fashion, aimed to pervade and colonize. Foucault described this process of governmentality as "tiny, everyday, physical mechanisms" by which the state reaches into its people (Kaplan 1995, p. 88; Foucault 1977, p. 222). He not only referred to politics and legitimate government, but to individuals watching and controlling each other. The colonial processes of discipline -- in particular, through schooling -- were the methods that allowed Egypt to be transformed into a capitalistic society (Mitchell 1991, p. 35).

Indeed, the slow rise of capitalistic society and authoritarian regime was pushed into place throughout this period of time. The British made their way into Egypt through the 1840's due to economic factors -- most importantly, the freshly-created route to India, which caused Britons to move into Egypt in much higher numbers than before. This stream of wanderers resulted in escalating Western immigration, along with Egypt's new place as a key cotton producer in European economy. The cultivation of cotton encouraged private ownership and created a class of landless employees, alongside utilization of wage-labor. Around that point, the “extravagant” Khedive Ismail -- then Egypt's ruler under the Turkish Ottoman Empire -- had stockpiled an immense amount of debt by attempting to reproduce European architectural structures in Egypt (Braddon 1988, p. 15). He was obligated to sell his shares in the Suez Canal to Great Britain. Because they had gained political power in Egypt, the British were able to strategically compete for bids on construction projects.

The establishment of the Suez Canal (a largely French enterprise, started in 1859 by Ferdinand de Lesseps) and new modes of infrastructure required giant influxes of migrant workers, all of whom were placed under careful police supervision by the British. "Tickets" were given to southern Egyptian workers as permission to travel north, unless they were deemed troublemakers (Mitchell 1991). Then, the Urabi Revolt, lined up by Egyptians to derail European economic control in Egypt, was macerated by British military. The "Veiled Protectorate" quickly came to light -- the Khedive was still considered the official leader of Egypt, but the British Consul-General and his advisers were truly in charge. Egyptian government members were dismissed from their positions if they did not obey their British superiors, and opportunities for business were given to the British at the expense of Egyptians, deepening the foundational roots of imperialism (Mak 2012, p. 8-12). The applied concept of Foucauldian government rolled onwards. With British takeover of Egyptian government, peasant revolutions were overcome by 
Maneto: The Temple University Multi-Disciplinary Undergraduate Research Journal | 2.1

use of torture, military raids, and informants. Close inspection was exercised everywhere (Mitchell 1991, p. 116).

Crime reports greatly spiked in 1884 , leading to new measures to combat brigands. Unlike European brigands, who lived in isolated areas and committed their lives to pillaging, Egyptian gang robbers were usually part-time criminals. This increase in crime was, by the British, considered a revolt in response to the change of "arbitrary methods of governing" to ones that revolved around rights of the individual. Traditional practices of living were dismantled by capitalistic economy, promoting crime. Communal systems were broken and replaced with private landholding, and bartering was traded for cash economy. This strengthened the rich and weakened the poor, providing the need for less fortunate Egyptians to explore alternative, criminal ways of making sufficient income. Regardless of implemented laws, like the Commission of Brigandage and the Ghaffir Law (both in 1884), brigandage continued to heighten across the country (Tollefson 1999, p. 27-29).

World War I (1914-1918) enlarged the Ottoman Empire, which then occupied land from the Black Sea to the Persian Gulf. Turkish forces were able to threaten the British without any difficulty, as they had both the Suez Canal and Britain's oil supplies. After a sequence of humiliating defeats in the Middle East, battered British troops decided to wrestle their way into Baghdad once again. Now, the Sykes-Picot agreement, secretly concocted between Britain, France, and Russia, decided that with the collapse of the Ottoman Empire, the Middle East would be cleanly split amid the three countries. The British succeeded in occupying Baghdad, and, in turn, the Turkish military surrendered, with the help of Arabs -- whose requests were never fulfilled by Great Britain (Braddon 1988, p. 17-24).

The Suez Crisis was first stirred in 1951. Egypt rejected Israeli ships from sailing the Suez Canal; Israel declined to allow Arab refugees to return home. The Anglo-Egyptian Treaty was to end soon, and Egyptians had started to attack British troops. Negotiations were requested, but King Farouk was resistant to changes. Finally, the Egyptian government repealed the treaty in 1954, when the British refused to leave Egypt. This was the same year the Nasser regime accepted the Aswan Dam project, funded partially by Americans, who hoped for Nasser to conciliate with Israel. Unfortunately, Egypt committed a heinous crime in the eyes of Americans by recognizing communist China, and Egyptian peace with Israel seemed to become more and more unlikely. Anti-communist US Secretary of State John Foster Dulles withdrew American 
Maneto: The Temple University Multi-Disciplinary Undergraduate Research Journal | 2.1

support of the Aswan Dam, worsening Egypt's deteriorating economic state (Braddon 1988, p. 43-46). At the same time, Egypt faced a massive malaria outbreak and famine among peasants, aggravated by fresh paths -- i.e. the Aswan Dam -- for viruses to spread (Mitchell 2002). Nasser was enraged, and moved to nationalize the Suez Canal. His vengeful goal was to produce more revenue than the US ever could have given (Braddon 1988, p. 48-49).

Britain and France were infuriated, as they had privately owned and operated the canal. Secretly concocting again, the two countries quietly planned, with Israel, to conquer Egypt and overthrow Nasser. The Sinai Peninsula was invaded in 1956 by Israeli forces, so the French and British joined. They vacated the Suez Canal when the US intruded the occupation (a comeback to threats of Soviet intervention). Britain, Israel, and France were seriously injured by this event, losing an extraordinary amount of international power (Lawler and Mahan 2010).

Some influences of European imperialism in the Middle East are clearly evident today -French and English are still commonly spoken among "educated classes" throughout Egypt, and French is often determined as Lebanon's unofficial second language (Central Intelligence Agency 2017). But the social and economic marks left on Middle Eastern society are just as deep-seated as language standardization. Postcolonial theory often discusses the constructed reliance on colonizer countries for economic support. In "Colonialism and State Dependency", Gerald Taiaiake Alfred mentions the colonization of British Columbia by white settlers. He then briefly talks about the settlers' efforts to generate economic dependency by destroying indigenous Canadians' subsistence-based systems, like fishing. While fishing camps were often attacked and raided, native fishers were also forced into wage-labor through regulatory practices and policies. Because government services were not provided in unrecognized rural areas, indigenous Canadians were pushed into urban centers, pressured into providing cheap labor, and removed from subsistence-based ways of life. In other words, their means of production were stolen from them them (Alfred 2009).

Egypt, through centuries of European colonialism, struggled for independence and then struggled to escape institutionalized dependency on colonizer countries. The Suez Canal, primarily assembled by the French, commenced the rush of political and ecological issues that plagued Egypt for hundreds of years, ones that continue to this day. 
Maneto: The Temple University Multi-Disciplinary Undergraduate Research Journal | 2.1

The Suez Canal facilitates at least one-tenth of world trade, and remains, internationally, a vital navigation lane. Despite this, preceding its 2015 expansion, the canal generated around $\$ 5$ billion per year, since the canal only allowed for one-way travel and was too narrow for an increasing number of giant ships, which had to steer through the Cape of Good Hope instead. The new project aimed to widen the canal by 35 kilometers and deepen the canal by 37 kilometers. It also necessitated the construction of eight underground tunnels for the Egyptian Armed Forces (Kenawy 2015).

Although this idea was suggested in the 1970's, it was only recently executed in reaction to Egypt's ongoing economic crisis and extremely high unemployment rates. The 80's brought with it depressed oil prices, caused by the Iran-Iraq War. Low-skilled labor jobs were found predominantly in other Gulf states, such as Saudi Arabia, which provoked a rise in Egyptians leaving for better opportunities. The acute downturn of Egypt's economy began after 1985 (Amīn 1995). In 2011, the revolutionary transformation of Egypt's government from Morsi's ruling regime to democracy targeted future achievement of social justice and maximum use of available resources. President Abdel Fattah el-Sisi was then elected into office, and began a series of projects to reform the struggling Egyptian economy. Threatened by the development of Israel's Eilat port, Russia's waterway in the North Pole, and the expansion of the Panama Canal, the Egyptian government decided to broaden the Suez Canal in order to double its annual revenue to about $\$ 13.226$ billion by 2023 (Kenawy 2015). Unfortunately, ecological effects were generally ignored in light of the economic benefits the expansion would bring, though, in 2015, a group of 17 scientists protested the expansion through an article published in Biological Invasions (Galil, et al. 2015).

The Suez Canal has always brought forth introduced species, as it connects the Red Sea and the Mediterranean Sea, two vastly different bodies of water. For some time, the hypersaline Great Bitter Lakes blocked foreign creatures voyaging the canal, as they were completely dry until 1869, when they filled with seawater. An enormous salt deposit had formed in the deep basin before this flood. The Bitter Lakes were of much higher salinity than the Red Sea and the Mediterranean, but unhurriedly settled down after the $160 \mathrm{~km}$. long Suez Canal opened (BenTuvia 1973). Studies have shown that parts of the southern canal are sometimes saltier than the Great Bitter Lakes themselves (Morcos and Messieh 1973). Another component was the Aswan Dam, which occluded the outflow of the Nile River. This decreased salinity in the northern zone 
Maneto: The Temple University Multi-Disciplinary Undergraduate Research Journal | 2.1

of the Suez Canal (Spanier and Galil 1991, p. 102-103). At the same time the Aswan Dam was erected in 1964, the Egyptian sardinella fishery collapsed (Ben-Tuvia 1973). Today, Egyptian purse seine fishing withdraws only $10 \%$ of the pre-dam catch, thanks to halting of nutrients and sedimentation in the Mediterranean (Golani 1998).

One of the earliest reports of invasive fauna in this region, transported from the Mediterranean to the Suez Canal, was recorded in 1883 (Oren 1969, p. 2). But the influx of introduced creatures became noticeable in the 1970's, when the method of analyzing new migrants shifted from recording new arrivals to examining the impacts of such species, and the dynamic circumstances that allow them to successfully migrate (Golani 1998; Ireland 2015). The past hypersalinity of the Bitter Lakes held off these migrants -- only the hardiest organisms could survive in such conditions. Eventually, the salinity dissipated into either side of the canal, and climate change set forth higher temperatures in the Mediterranean, a more suitable situation for creatures of the warmer Red Sea (Morcos and Messieh 1973, p. 123; Ireland 2015). Since then, populations of Lessepsian migrants have increased tenfold: nearly 420 introduced species have been uncovered thus far, mostly mollusks, crustaceans, annelid worms, and algae (Boudouresque 1999; Ireland 2015).

Lessepsian migrants, named for the Suez Canal's mastermind, Ferdinand de Lesseps, menace Mediterranean industries mainly through outcompeting native species and net clogging, which can cause boats to discard entire catches (Ireland 2015). Throughout the 1980's, marine fisheries constituted around 22\% of Egypt's total fish production; the Nile yielded $11 \%$, lakes $51 \%$, and aquaculture $17 \%$. In 2012, marine fisheries provided $8.3 \%$, the Nile $4.9 \%$, and lakes 12.6\%. Aquaculture production swelled to approximately 74.2\% (Mehanna, Abd, and Belal 2016). The remaining area surrounding the Mediterranean has been equally afflicted. By 1973 , $21 \%$ of Israel's trawl fishing catch and $8 \%$ of their inshore catch was composed of invasive species (Ben-Tuvia 1973). In more recent studies, it has been shown that the amount of migrant fish received has expanded to a third of Israel's trawl catch (Galil 1997).

The Mediterranean experienced its "Pelagia years" in the 80's, when funds were poured into investigating jellyfish blooms that had become of concern to local fishers and the tourism industry (CIESM 2001). These large, powerful sea jellies, Rhopilema nomadica (the nomad jellyfish), aggregated into enormous clusters, estimated at 25 bodies per cubic meter during summer. This propelled massive consequences for Turkey, Lebanon, Israel, Cyprus, and Egypt 
Maneto: The Temple University Multi-Disciplinary Undergraduate Research Journal | 2.1

(Galil 1997). Injuries, contaminated catches, and clogged nets were some repercussions of the nomad jellyfish bloom, which was never fully mended. Because the nomad jelly's sting calls for immediate hospitalization, countries around the Eastern Mediterranean that rely on tourism were brutally impaired (Öztürk and İşinibilir 2010).

Fishers have exploited introduced species and given Lessepsian migrants economic importance; for example, in Egypt, the conspicuous blue crab, Portunus pelagicus. However, replacement of a species does not always make up for external costs. Caulerpa taxifolia, a common seaweed, was found to colonize vast meadows of endemic Posidonia oceanica in the Mediterranean. In 1996, it was recorded to have taken over more than 6,000 hectares of the seafloor; in 2000, over 13,000 hectares (Streftaris and Zenetos 2006). According to the local fishermen, this "killer alga" caused dramatic decrease in catches, which caused them to travel farther for their work, involving more fuel and more powerful boats (Boudouresque 2002, p. 7587; Streftaris and Zenetos 2006).

Overseas labor remittances and tourism, pre-expansion, individually accounted for more of Egypt's national income than the Suez Canal (Kenawy 2015). Though the revenue of the canal is expected to double, Egypt's tourism sector may be deeply affected by the ecological effects of the Suez Canal's expansion. The South Sinai Peninsula is recognized for its coastal tourism industry (composing $90 \%$ of its earnings), and along its borders, fishing thrives in the Gulf of Suez and the Red Sea (Tesfamichael and Mehanna 2012). Egypt's fishers will be profoundly affected as native species continue to be replaced by introduced organisms that may not hold as much value. As of 2017, Egypt's unemployment rate is a startling 34.3\% (Central Intelligence Agency 2017). The expected doubled revenue of the expanded Suez Canal is predicted to be reached in 2023 (Kenawy 2015).

In the meantime, it is fair to ask if there is a different way of approaching the Egyptian economic crisis, one that addresses the negative ecological effects that come with maximizing the potential of natural resources. Harvey suggests that our current system marks nature as a "passive set of assets" to be talked about in monetary terms, and that present environmental practices are profit-driven. Those with social power require environmental issues to be solved through exchanges of money (Harvey 1996). This often results in neoliberal solutions, more based on keeping profits than taking care of the environment and human welfare directly affected by the environment. Marxist theory implies that the goals of capitalism are not aligned with 
Maneto: The Temple University Multi-Disciplinary Undergraduate Research Journal | 2.1

environmental conservation. Capitalist production requires an extraction of surpluses from labor and nature, which intensifies quickly, as the system depends on further growth (Robbins 2011).

But because the environment and human society transform based on one another's changes, environmental conservation is vital to consider, especially in a country undergoing economic crisis. So while it seems impossible to move forward in any environmental problems alongside the maximization of efficiency and revenue, there are a couple possible methods of mitigating the Suez Canal's negative ecological effects within the current system. There are plausible short-term techniques of control. In the Atlantic Ocean, culling efforts on invasive lionfish have reduced populations greatly, sometimes stabilizing or even reversing declines in native species that were previously diminishing (Côté et al. 2014). Egyptian fishers have already begun hauling invasive fish in replacement of native species, so this is a viable alternative (though, as mentioned before, fishers' revenues may be greatly affected by external costs). Additionally, if money is spent cleaning up the flurry of invasive creatures in the Mediterranean, long-term revenue may increase as a product of a healthier fishing sector.

Nonetheless, it is more important to take into account the roots of damage. The algae and sea jelly blooms throughout the afflicted bodies of water signal not only differences in salinity and temperature, but also eutrophication. An influx of nitrates and phosphates most likely comes from local factories and farms disposing of their chemicals (or in the case of farms, fertilizers). Around $90 \%$ of Egypt's water supply depends on the Nile, and one of the largest industrial regions in Egypt, Shubra El-Kheima, is situated next to it. Its most productive sources of income are its textile and garment industries, two undeniably dedicated abusers of fossil fuels. Toxicmetal concentrations in edible plants were recorded to have increased throughout the 80's and 90's (Ali 1993). Discharge of factory chemicals and fertilizers into the Nile, no matter where the offense happens, directly affects faraway towns. The city of Ismailia, which relies on the brackish Lake Timsah as its main source of money, has found fish production halved in recent years. This is partly an outcome of overfishing and illegal methods of fishing, but is also ascribed to pollution from the Nile, as well as vast changes in salinity and temperature (Mehanna, Abd, and Belal 2016).

Shubra El-Kheima is not the only offender. A water quality assessment conducted in 2004 showed the Alexandria region to be equally guilty of dispensing pollutants into local sources. A survey made by the Drainage Research Institute displayed that at least 17 factories 
discard directly into Lake Maryut. 22 factories discard through drains connected to the lake. The amount of material dispensed is equivalent to "untreated discharge of wastewater from more than six million people" (Wahaab and Badawy 2004). These statistics exhibit both an environmental issue and a human health issue. Though the Suez Canal opened a route for Lessepsian migration, the effects of migration are worsened by eutrophication. Without frequent algae blooms, incursions of jellyfish would be uncommon.

What do these statistics imply? European demand for the Suez Canal resulted in an ecological crisis, one that plagues Egypt even today. Thus, French and British colonial rule are still in control of Egyptian ecology, economic stability, and politics. Unless Egypt is untangled and reformed from its colonial background, progress will not be made. The Suez Canal should not be one of the only steady and reliable sources of income for the nation, as the structure in itself guards Egypt from other historical sources of income, such as tourism and fishing. It is also the major route used by European maritime companies to transport goods, meaning it fosters a connection to Western Europe. With a reliance on industries supported, funded, and encouraged by former colonists, the country cannot move away from an struggling economy contingent on the Global North. 
Maneto: The Temple University Multi-Disciplinary Undergraduate Research Journal | 2.1

\section{References}

1. Alfred, G. T. (2009). Colonialism and state dependency. Journal of Aboriginal Health, 5(2), 42-60.

2. Ali, E. A. (1993). Damage to plants due to industrial pollution and their use as bioindicators in Egypt. Environmental Pollution, 81(3), 251-255.

3. Amīn, Ğ. A. (1995). Egypt's economic predicament: A study in the interaction of external pressure, political folly, and social tension in Egypt, 1960-1990 Brill.

4. Attar, S. (2010). Debunking the myths of colonization: The Arabs and Europe. Blue Ridge Summit, US: UPA.

5. Belmaker, J., Parravicini, V., \& Kulbicki, M. (2013). Ecological traits and environmental affinity explain red sea fish introduction into the mediterranean. Global Change Biology, 19(5), 1373-1382. doi:10.1111/gcb.12132

6. Ben-Tuvia, A. (1973). Man-made changes in the Eastern Mediterranean sea and their effect on the fishery resources. Marine Biology, 19(3), 197-203.

7. Boudouresque, C. F. (1999). 14 the Red Sea-Mediterranean link: Unwanted effects of canals. Invasive species and biodiversity management (pp. 213-228) Kluwer Academic Publishers Dordrecht.

8. Boudouresque, C. (2002). The spread of non-native marine species, Caulerpa taxifolia. impact on Mediterranean biodiversity and possible economic consequences. In F. di Castri, \& V. Balaji (Eds.), Tourism, biodiversity and information (pp. 75-87). Leiden, The Netherlands: Backhuys Publishers.

9. Braddon, R. (1973). Suez--splitting of a nation. London: Collins. 
Maneto: The Temple University Multi-Disciplinary Undergraduate Research Journal | 2.1

10. CIESM. (2001). Gelatinous zooplankton outbreaks: Theory and practice. In The Mediterranean Science Commission (Ed.), CIESM workshop monographs () CIESM Workshop Monographs.

11. Côté, I. M., Akins, L., Underwood, E., Curtis-Quick, J., \& Green, S. J. (2014). Setting the Record Straight on Invasive Lionfish Control: Culling Works,

12. Foucault, M. (2012). Discipline \& punish: The birth of the prison. Vintage.

13. Galil, B. S. (1997). Biodiversity and invasion-- how resilient is the Levant Sea? Israel Environ.Bull., 20(1), 20-21.

14. Galil, B., Boero, F., Fraschetti, S., Piraino, S., Campbell, M., Hewitt, C., et al. (2015). The enlargement of the Suez Canal and introduction of non-indigenous species to the mediterranean sea. Limnology and Oceanography Bulletin, 24(2), 41-43. doi:10.1002/lob.10036

15. Galil, B., Boero, F., Campbell, M., Carlton, J., Cook, E., Fraschetti, S., et al. (2015). 'Double trouble': The expansion of the Suez Canal and marine bioinvasions in the Mediterranean sea. Biological Invasions, 17(4), 973-976. doi:10.1007/s10530-014-0778-y

16. Harvey, D., \& Braun, B. (1996). Justice, nature and the geography of difference. Wiley Online Library.

17. Horst, J., Jünemann, A., Rothe, D., \& MyiLibrary. (2013; 2014; 2016). Euro-Mediterranean relations after the Arab Spring: Persistence in times of change (New ed.). Burlington, VT, USA; Farnham, Surrey, England: Ashgate.

18. Ireland, T. (02). The great invasion. New Scientist (1971), 225(3010), 46; 46-47; 47.

19. Jeffreys, D. (2003). Views of ancient Egypt since Napoleon Bonaparte: Imperialism, 
Maneto: The Temple University Multi-Disciplinary Undergraduate Research Journal | 2.1

colonialism and modern appropriations. London: UCL Press.

20. Kaplan, M. (1995). Panopticon in Poona: An essay on foucault and colonialism. Cultural Anthropology, 10(1), 85-98. Retrieved from http://www.jstor.org/stable/656232

21. Kenawy, E. M. (2015). The expected economic effects of the new Suez Canal project in Egypt. European Journal of Academic Essays, 1(12), 13-22.

22. Lanver, M. (2012). The British in Egypt: Community, crime and crises 1882-1922. Volume 74 of International Library of Historical Studies (74th ed., ) I.B.Tauris.

23. Lawler, D., \& Mahan, E. (2010). Foreign relations of the United States. Retrieved March 6, 2017, from https://history.state.gov/milestones/1953-1960/suez

24. Mehanna, S. F., Abd El-Azim, H., \& Belal, A. A. (2016). Impact of metal pollution, food availability, and excessive fishing on Rhabdosargus haffara stock (family: Sparidae) in Timsah Lake. Environmental Science and Pollution Research, 23(16), 15888-15898. doi:10.1007/s11356-016-6915-7

25. Morcos, S. A., \& Messieh, S. Circulation and salinity distribution in the southern part of the Suez Canal.

26. Oren, O. (1969). Oceanographic and biological influence of the Suez Canal, the Nile and the Aswan Dam on the Levant Basin. Progress in Oceanography, 5, 161-167.

27. Öztürk, B., \& İşinibilir, M. (2010). An alien jellyfish Rhopilema nomadica and its impacts to the eastern Mediterranean part of Turkey. Journal of Black Sea/Mediterranean Environment, $16(2)$

28. Por, F. D. (1971). One hundred years of Suez Canal - a century of Lessepsian migration: Retrospect and viewpoints. Systematic Biology, 20(2), 138-159. 
Maneto: The Temple University Multi-Disciplinary Undergraduate Research Journal | 2.1

29. Purcell, J. E., Malej, A., \& Benović, A. Potential links of jellyfish to eutrophication and fisheries. Ecosystems at the Land-Sea Margin: Drainage Basin to Coastal Sea, , 241-263.

30. Robbins, P. (2011). Political ecology: A critical introduction John Wiley \& Sons.

31. Shackley, M. (1999). Tourism development and environmental protection in southern sinai. Tourism Management, 20(4), 543-548.

32. Spanier, E., \& Galil, B. S. (1991). Lessepsian migration: A continuous biogeographical process doi:http://dx.doi.org/10.1016/0160-9327(91)90152-2

33. Streftaris, N., \& Zenetos, A. (2006). Alien marine species in the mediterranean-the 100 'Worst invasives' and their impact. Mediterranean Marine Science, 7(1), 87-118.

34. Tesfamichael, D., \& Mehanna, S. (2012). Reconstructing red sea fisheries of Egypt: Heavy investment and fisheries. Catch Reconstruction for the Red Sea Large Marine Ecosystem by Countries (1950-2010). Fisheries Centre Research Reports, 20(1), 23-50.

35. Tollefson, H. (1999). Policing Islam: The British occupation of Egypt and the AngloEgyptian struggle over control of the police, 1882-1914 Greenwood Publishing Group.

36. Wahaab, R. A., \& Badawy, M. I. (2004). Water quality assessment of the River Nile system: an overview. Biomedical and environmental sciences, 17(1), 87-100. 